\title{
Uneven convergence in development? The case of India's lines of credit to Africa
}

Link to publication record in Manchester Research Explorer

\section{Citation for published version (APA):}

Dye, B. (2020). Uneven convergence in development? The case of India's lines of credit to Africa.

FutureDAMS/IUKDP Working Paper.

\section{Citing this paper}

Please note that where the full-text provided on Manchester Research Explorer is the Author Accepted Manuscript or Proof version this may differ from the final Published version. If citing, it is advised that you check and use the publisher's definitive version.

\section{General rights}

Copyright and moral rights for the publications made accessible in the Research Explorer are retained by the authors and/or other copyright owners and it is a condition of accessing publications that users recognise and abide by the legal requirements associated with these rights.

\section{Takedown policy}

If you believe that this document breaches copyright please refer to the University of Manchester's Takedown Procedures [http://man.ac.uk/04Y6Bo] or contact uml.scholarlycommunications@manchester.ac.uk providing relevant details, so we can investigate your claim.

\section{OPEN ACCESS}



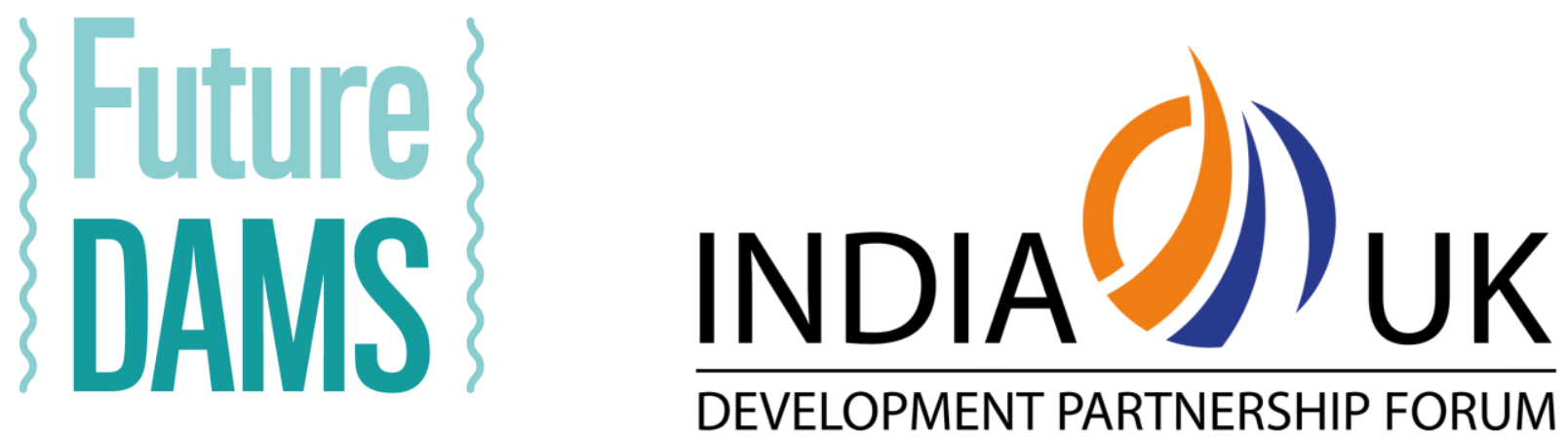

Design and Assessment of

water-energy-food-environment

Mega-Systems

\section{Uneven convergence in development? The case of India's lines of credit to Africa}

Barnaby Joseph Dye ${ }^{1}$

${ }^{1}$ Global Development Institute, The University of Manchester, UK

\section{FutureDAMS \& India UK Development Partnership Forum}

\section{Working Paper}

December 2020

Cite this paper as: Dye, B. (2020) Uneven Convergence in Development? The Case of India's Lines of Credit to Africa. FutureDAMS/IUKDP Working Paper 014. Manchester: The University of Manchester. 


\section{Abstract}

This paper examines the uneven convergence between Indian development cooperation and the (so-called) 'traditional' development establishment. Using the case of Indian government concessional lines of credit (LoCs), handled by the Export-Import Bank, it demonstrates how diplomatic, strategic and party-political interests drove a major revision in LoC policy in 2015. The Indian government directly adopted policies from the World Bank and the UK's Department for International Development on project selection and design, tendering and monitoring. These were designed to increase technical proficiency, timeliness and development outcomes but also to bring about a change in the companies undertaking these projects. Such policies indicate some degree of departure from the non-interventionist, non-hierarchical norms of India's original South-South Cooperation, whereby the recipient (in theory) exclusively made decisions over what projects were done and how. To some extent, that role is now shared. This partially mirrors changes among the DAC donors, many of whom are redefining the definition of OECD Official Development Assistance (ODA), increasing blended finance and focusing more on economic development (and less on poverty reduction). However, while converging in these aspects of technical planning and implementation, the political and strategic interests driving the LoC changes did not extend to examining developmental or environmental outcomes; state-to-state relations continue to have primacy in the project-approval process. The paper therefore finds uneven convergence in India's development cooperation, with change in technical policies but greater persistence in norms. This reflects the wider multidirectional evolution of the global development sphere.

\section{Keywords}

Development, infrastructure, Exim Bank, India-Africa relations, politics, dams, lines of credit, Rwanda

\section{JEL Codes}

O13, O21, O55, P41, P48, Q48

\section{Acknowledgements}

I would first like to thank Udisha Saklani, who provided invaluable support as a research assistant collecting a statistical base which was used for the quantitative analysis presented here. I also acknowledge the fieldwork support, introductions and advice given by key contacts, including Dr Renu Modi, Dr Emma Mawdsley, Dr Maan Barua and Professor Ricardo Soares de Oliveira, who was my doctoral supervisor when I first started this research. For my 2020 fieldtrip, I thank the logistical support provided by the Institute for Economic Growth, Delhi. Earlier drafts were greatly improved by comments from Dr Mawdsley, Dr Taggart and an anonymous reviewer. The research behind this paper was conducted between 2014 and 2020 and supported by the UK's Economic and Social Science Research Council (ESRC) under [Grant No. ES/J500112/1] through 3+ Doctoral Scholarship, the FutureDAMS research (UK Research and Innovation-Economic and Social Research Council [ES/P011373/1]) project and the India-UK Development Partnership Forum. I do not believe there was any conflict of interest in the production of this paper. 


\section{Contents}

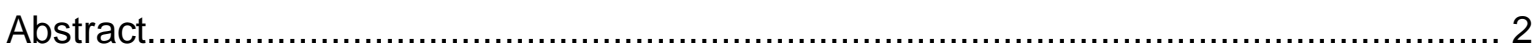

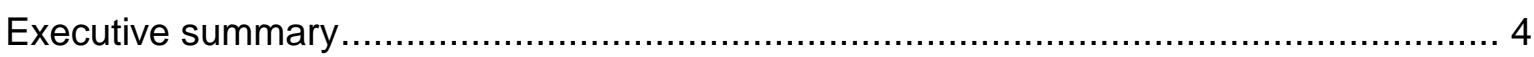

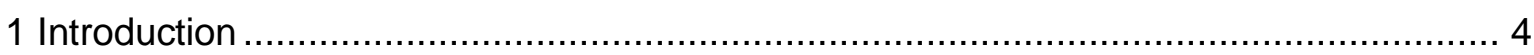

2 Multidirectional convergence between the Global North and Global South.................... 6

3 The evolution of India's development cooperation.............................................. 9

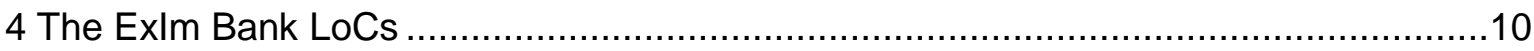

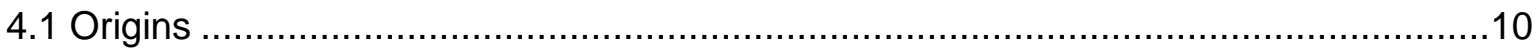

4.2 Evolution: non-conditionality to imposed standards ............................................11

2005-10: the primacy of a political, not project-based decision ..................................... 11

2010-15: light-touch regulation and growing bureaucracy ......................................... 11

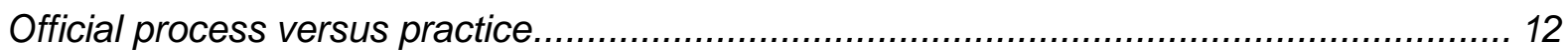

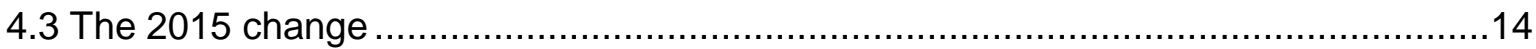

5 How far is this a shift from earlier South-South cooperation? The unevenness of convergence

6 Motivations for the 2015 changes to IDEAS: bilateral relations merged with corporate and political interests

7 The unintended consequences of convergence and the overlooked factors underpinning

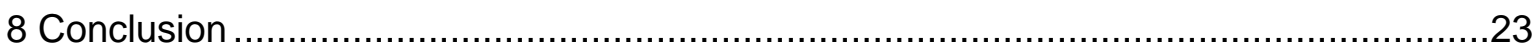

References 


\section{Executive summary}

The rules governing India's state-owned ExIm Bank lines of credit (LoCs) changed in 2015.

Project planning, scrutiny and monitoring increased, alongside open competitive tendering.

Another key change involved introducing project management consultants.

Ostensibly, the aim was technical proficiency: functioning projects, delivered on time and within budget.

Indian diplomacy wanted to create goodwill among African governments.

Additionally, the government and larger infrastructure corporations wanted to prohibit the involvement of politically connected firms.

Previously dominant 'entrepreneurial', inexperienced firms were essentially excluded.

Indian interests therefore drove convergence in development practices, with World Bank and UK policies directly adopted.

However, convergence did not occur in the assessment of projects' developmental, social or environmental impact.

African governments are concerned about the new rules' lengthiness and their (governments') inability to control tendering.

This decreased the uptake of LoCs in Africa post-2015.

\section{Introduction}

On the $20^{\text {th }}$ October 2015, on the eve of a major governmental India-Africa Forum Summit, the Indian Express published an explosive article about the country's flagship development cooperation scheme, the concessional lines of credit (LoCs). It exposed how four relatively new and unqualified companies had bagged a large share of the loans to Africa (lyer, 2015). The Export-Import (Exim) Bank, the government agency handling this concessional credit, had raised a 'red flag', posing questions about how such companies had become involved in the majority of LoCs. The drama intensified as, a few months later, in February 2016, India's Enforcement Directorate raided former ambassador Deepak Vohra's homes (The Times of India 2016). ${ }^{1}$ Vohra had worked with the largest of the four companies, Angelique, to secure contracts in Africa. Corruption was suspected. These events coincided with the India-Africa summit that Prime Minister Narendra Modi had planned to mark a new era for India-Africa relations. Unlike the first high-level political forums in 2008 and 2011 (Cheru \& Obi, 2011; Taylor, 2016), which were limited to 15 African countries, ${ }^{2}$ the 2015 summit drew world attention for its spectacle and the red-carpet treatment of delegations from all 54 African countries. The scale of the 2015 event was intended to demonstrate India's increased level of commitment to and action on the continent and Modi made bold promises to rapidly scale development cooperation, including a doubling of LoCs to US $\$ 10$ billion, and a pledge to offer $\$ 600$ million in grant assistance and 50,000 scholarships.

\footnotetext{
1 'ED raids former Indian diplomat on suspicion of "line of credit" fraud'. Times of India, 2 February 2016.

${ }^{2}$ Chosen according to the African Union's Banjul formula.
} 
However, the LoC scheme was attracting controversy and complaints. Reportedly, African leaders were raising concerns about delays and problems around the completion of LoC projects at the summit and at other bilateral meetings. ${ }^{3}$ Moreover, the press revelations suggested malfeasance. Thus, in November 2015, a new set of regulations for concessional credit were introduced, increasing scrutiny, intervening in the selection and design of projects and transforming the tendering process to one managed 'in-house' by the Exim Bank. Significantly, these marked a change from the previous non-interventionist, sovereignty-first, demand-led policy associated with South-South Cooperation. Alongside a wider shift among policymakers' vision for India's development cooperation, these changes demonstrated a degree of convergence with the policies of mainstream 'Western' development institutions represented by the OECD's Development Assistance Committee (DAC) and the World Bank.

This paper has found such convergence to be uneven: while the 2015 changes aimed to improve the technical proficiency and timeliness of projects, they retained an almostexclusive focus on state-to-state relations, overlooking projects' developmental outcomes for citizens and the environment. The paper demonstrates that the change in policy had unintended consequences in Africa, reducing the uptake of LoCs. The strategic foreign policy interests in the Ministry of External Affairs (MEA) drove the LoC changes, with technicians in the Development Partnership Authority and Exim Bank believing adoption of particular World Bank and DAC donor policies were the best way of achieving their aims. The changes also gained support from large infrastructure companies, which stood to gain from a greater share of LoC contracts, and from ruling Bharatiya Janata Party (BJP) partypolitical actors, who wanted to exclude Congress Party-linked companies. Therefore, civil servants, corporates and politicians were not influenced by a desire to join the international development establishment, and in fact rejected any such semblance. Convergence occurred in particular technical practices, but not significantly in the expression of norms and rhetoric.

This evidence contributes to the debate about whether, and how, convergence between 'Southern' and 'Western' powers is occurring. This is a debate that sometimes presents as a simplified binary of whether the emerging powers will disrupt and innovate, or adopt and integrate into the existing norms and policy frameworks of the international community (even as these continuously evolve). In contrast, this paper is premised on the multidirectional nature of recent convergence. It is rooted in Mawdsley's conception of 'South-South Cooperation 3.0' (Mawdsley, 2019), an era where 'new' donors have adopted selective norms and practices associated with DAC donors and Bretton Woods institutions in order to carry out their increasing economic, diplomatic and cooperation engagements in developing countries. Meanwhile, DAC donors have simultaneously become more 'Southern', with their aid focused on economic growth and informed by strategic state-to-state relations (Mawdsley, 2015, 2018). To tackle this, a number of academics (Xiaoyu, 2012; Fejerskov et al, 2017) have called for precise analysis of where convergence is and isn't happening, as well as of its nuances; for example, where it may be functional (e.g. in creating new agencies

\footnotetext{
3 https://economictimes.indiatimes.com/news/economy/policy/modi-government-approves-ideasscheme-to-streamline-loc-to-make-indian-funding-attractive/articleshow/50360769.cms?from=mdr; interviews with journalists in Delhi, 2016.
} 
or practices) versus normative. This paper's detailed empirical analysis responds to this call, and differentiates between norms, expressed through rhetoric about values and ambitions, and practices, which for our purposes refer to official policies and the enacting of them. The paper's case study of India's LoCs demonstrates uneven convergence. This term captures the selective rather than universal changes in development practices, and the smaller evolution in norms. It suggests that international relations and development will continue to experience persistent heterogeneity amid convergence, with technical and managerial adoption occurring to a greater extent than standards around socio-environmental impacts that require greater intervention.

The paper is the product of primary fieldwork carried out between 2016 and 2020. It involved conducting 65 semi-structured interviews with key officials in Delhi and Mumbai, alongside interviews in Ghana. Interviewees included present and former MEA diplomatic staff and officials from the Development Partnership Administration (DPA) and Exim Bank.

Additionally, interviews were conducted in influential foreign policy think-tanks, private-sector federations, and infrastructure companies operating in Africa and among academics studying India-Africa relations. Statistics on the LoCs were helpfully gathered by Udisha Saklani, a postgraduate at Cambridge University, and used by the author to understand trends and contracting patterns. This was undermined by the lack of statistics on the contracting of LoCs. The following section grounds this paper, first in the literature on convergence, and then through a discussion of the evolution of India's development cooperation. It then details the 2015 changes to concessional finance and analyses the unevenness of convergence. This is not to argue that the DAC agencies' norms and practices are correct, that they achieve poverty reduction and do not cause socioenvironmental harm - far from it. Rather, the analysis reveals the internal Indian political and business interests that drove technical changes and a continued state-to-state focus. Thus, World Bank and DAC donor technical, engineering and procurement policies were adopted, but not those procedures designed (in theory) to achieve stronger developmental outcomes and minimise or mitigate socio-environmental impacts.

\section{Multidirectional convergence between the Global North and Global South}

The economic, political, technological and military rise of 'emerging powers' like India, Brazil and China has provoked much discussion in international relations literature about what consequences this has for the existing international system (Gray \& Murphy, 2013). Two perspectives quickly emerged, emphasising divergence and convergence. One divergence school of thought, focusing on 'hard' power factors like population, GDP and military strength, argued that the rising powers would usurp the established liberal order and increase the propensity for conflict (Khanna, 2009; Ikenberry, 2010). Equally, a 'Southern' divergence perspective made the case for maintaining difference from Western-led norms and the perceived inequality of the liberal order (Panda, 2013). In contrast, a larger body of work sees the rising powers reforming, but largely conforming to the liberal world order: as Hurrell (2014, p 93) writes, it is "often useful to analyse emerging powers in terms of how they are seeking to navigate the best position for themselves within a state-centric, liberal and capitalist order whilst accepting most of the underlying assumptions of that order". Partly, this rests on the assumption that, given their rise through the post-WWII Bretton Woods governance architecture, rising powers will not "be revolutionary. They do not differ 
from other powers, past or present, in wishing to extract as many benefits as possible from international engagement while giving up (minimal) ... decision making" (Kahler, 2013, p 712). The creation of the G20 illustrates this, merely expanding inclusion and shifting the balance of power within global governance forums (Hurrell, 2014). Additionally, Hurrell and Sengupta (2012), Narlikar (2007) and Hurrell and Narlikar (2006) have found substantive efforts to influence, rather than destroy or replace, the World Trade Organization (WTO), United Nations Security Council and UN climate change negotiations.

This convergence versus divergence debate has also played out in international development partnerships and financing. China in particular came in for un-nuanced critique, portrayed as a 'rogue aid' actor (Naim, 2009) or as neocolonial (Kohli, 2009; Michel et al, 2010; Okeke, 2014, Enns \& Bersaglio, 2020) for its seeking of natural resources and its mercantilist support for large and state-owned corporations. Beijing's engagement with Sudan's and Zimbabwe's former presidents have been held up as evidence of the Chinese government's destabilising effect on democracy and development efforts. However, these arguments have been strongly rebutted, perhaps most forcefully by Bräutigam ( 2011) and the China-Africa Research Initiative, who have demonstrated the developmental gains China has brought, the agency of African leaders in shaping ties and the degree to which the geography of China's investments matches that of Africa's other international players (Carmody, 2011, Mohan \& Lampert, 2013). Moreover, there is considerable evidence of 'Southern' powers increasingly adopting selected OECD-DAC group practices according to their perceived strategic interest. Most BRICS (Brazil, Russia, India, China, South Africa) have created development cooperation bureaucracies to handle the delivery of projects that somewhat resemble those of DAC donors: India's Development Partnership Administration (DPA and China's International Development Cooperation Agency were established in 2012 and 2018, respectively. Mawdsley (2019) reports that this has accompanied a stronger focus on outcomes and programme delivery, features associated with traditional DAC aid from the 1990 s especially. Further, a number of the emerging powers have engaged with the formal DAC policy-making process, attending the Busan talks in 2011. There are also signs of increasing attention being paid to socio-environmental and poverty outcomes: Brazil's development bank (BNDES) in 2012 (Hochstetler, 2014) and China's Exim Bank in 2008 (Hensengerth, 2013) introduced environmental impact assessments as a condition of their international infrastructure-project loans. This would all suggest the adoption of particular practices and architectures of 'traditional' DAC aid.

However, this convergence/divergence framing is too binary, missing the multiple directions of change over the past decade. For one, there are persistent differences and increasing fragmentation within the emerging powers, which leads to them practising South-South cooperation differently. India's current Prime Minister, Narendra Modi, has at times rejected the principles and rhetoric of solidarity espoused by Congress Party leaders (Harris \& Vittorini, 2018). Brazil's approach to South-South Cooperation has more dramatically shifted from the rhetoric, grand gestures and resources of President Lula's years to the meagre attention given by President Temer (2016-18) and the disinterest, if not rejection, of President Bolsanaro (2018- )(Marcondes \& Mawdsley, 2017; Dye \& Alencastro, 2020). China's Belt and Road Initiative, its flagship development cooperation programme, differs again. It is far larger than any other South-South cooperation initiative, is set to include 
OECD countries and has a geopolitical vision that contrasts with open, 'demand-led' SouthSouth Cooperation rhetoric.

Equally important is the 'Southernisation' of the supposedly 'traditional' aid actors of the OECD's DAC group. From the 1990s into the 2000s, there was a trend towards independent aid agencies whose mandates centred on poverty and development objectives, but this has been increasingly replaced by greater alignment to projections of national interest and associated foreign policy. This has been most overtly evident in the decision to merge the respective UK and Australian independent aid organisations into foreign affairs ministries in 2020 and 2013, respectively. For the UK's Department for International Development (DfID), this move represented the culmination of successive changes under a decade of Conservative government that pushed stronger alignment with the Foreign Office, support for British companies and use of aid money for private-sector investment (Mawdsley, 2015, 2018; Pamment, 2018). Such features have long existed among 'Southern' donors, ${ }^{4}$ with infrastructure finance typically attached to contracting domestic firms, for example. Infrastructure support has also returned, after concern about socio-environmental trade-offs drove a reduction from the mid-1990s. This is best illustrated by the resurgence in building large dams, one of the most controversial infrastructures, led in part by the World Bank (Dye, 2020). In addition, the US launched an infrastructure-finance facility (the US International Development Finance Corporation) and the UK's Commonwealth Development Corporation (now CDC Group) has backed a number of controversial private-sector infrastructure projects. ${ }^{5}$ This is part of a wider agenda to focus more clearly and explicitly on economic growth, rather than on poverty reduction directly. It is best symbolised by the transition from the UN's Millennium Development Goals to the Sustainable Development Goals. Thus, a shift has occurred among many of the actors associated with the 'traditional aid establishment' (Gulrajani \& Faure, 2019).

However, generalising this 'traditional' label is problematic, as considerable variation exists within it. The World Bank is influenced to some extent by 'Southern' countries through its boards of directors, especially after reforms over the past three decades. There are also numerous contrasts between bilateral DAC donors. Ideological fissures over the role of the private sector versus the state in delivering development exist, for example, between the Scandinavian agencies, such as Sweden's SIDA and Norway's NORAD, and USAID, while there are clear contrasts between those providing more technical support, e.g. Belgium's BTC and Germany's GIZ, and others, notably the Millennium Challenge Corporation, which focuses on policy change. Given such variety and the multidirectional nature of the development sector's evolutions, it is important to examine empirically where convergence is and isn't happening. For example, there is some debate about whether the creation of the New Development (BRICS) Bank and (China-led) Asian Infrastructure Investment Bank represents, on the one hand, conformity, given theirs institutions' similar architecture and recruitment from Bretton Woods institutions, or divergence, given their policies of greater non-interference and preference for large infrastructure (Serrano Oswald, 2019).

Multidirectional convergence within a widely heterogeneous group of actors is therefore

\footnotetext{
${ }^{4}$ In addition, to some extent in DAC ones like USAID.

5 Including luxury housing developments and fossil fuel extraction (\$744 million between 2014 and 2019). See CAFOD \& Wykes (2020).
} 
evident. However, debate continues between academics placing more emphasis on persistent differences (Xiaoyu, 2012) and those asserting ever-greater conformity (Horner, 2020). Kragelund (2015) sees China's development cooperation in Africa increasingly mirroring that of Western aid institutions, while Fejerskov et al (2017) argue that the emerging powers' ideas are not that distinct, and moreover, that they are increasingly adopting the monitoring standards of the DAC establishment. This paper, in contrast, presents empirical evidence of the unevenness of the convergence through an analysis of India's lines of credit scheme, to which we now turn.

\section{The evolution of India's development cooperation}

To provide an appreciation of the evolution of the Lines of Credit (LoC) scheme, this section reviews the history of India's South-South Cooperation. India's international development activity started soon after independence, championed and strongly shaped by the country's first Prime Minister, Jawaharlal Nehru. He was a key driver behind Afro-Asian solidarity and the Non-Aligned Movement (NAM) (Mawdsley, 2011, 2012) that pioneered the idea of South-South Cooperation, a framework for development assistance aiming to support postcolonial countries to avoid neo-colonial dominance by the capitalist or communist geopolitical groupings. The widely articulated principles of South-South Cooperation reject hierarchies between partners and asserts principles of demand-led, mutually beneficial, winwin cooperation. South-South Cooperation involves respect for each country's sovereignty, entailing a state-to-state focus that leaves the recipient to consider potential socioenvironmental impacts and understand their populations' best interests.

The principles of South-South Cooperation were the ideational foundation for India's development cooperation and foreign policy more widely, coexisting with evolving strategic foreign policy interests. These included dealing with conflict with China and Pakistan, which, in turn, rendered relations with other South Asian countries significant. Development cooperation is a useful tool for building such ties (Kumar \& Sharma, 2015; Bhatnagar et al, 2016). Equally, particularly regarding relations with Africa, development projects were expected to underpin goodwill, leading to votes in international multilateral fora like the United Nations (Dye \& Soares de Oliveira, forthcoming; Cheru \& Obi, 2011). Another objective has been supporting the internationalisation of Indian businesses. This grew with the successive rounds of deregulation from the 1980s, accelerating into the 1990s, that allowed India's private sector to expand and internationalise. Consequently, the private sector has called on the state to offer more support, lobbying particularly through business federations like the Confederation of Indian Industries (CII) and the Federation of Indian Chambers of Commerce \& Industry (FICCI) (Dye \& Soares de Oliveira, forthcoming).

These interests are fairly standard in foreign ministries. Nor do they signify an end to the South-South Cooperation principles. Harris and Vittorini (2018), for example, assert that such interests still shape India's African development activity and its non-conditionality. Further, others, like Modi (2010, 2013a, 2013b), have shown how the relative sophistication and relative low cost of India's healthcare, and its agricultural technology, make collaboration in these fields mutually beneficial for India and the African continent. Jain Irrigation Systems, Kirloskar Brothers and ISCO Fertiliser are all present in Africa, for instance. The Indian Technical and Economic Cooperation (ITEC) scheme, established in 1964 as the key 
programme for delivering Nehru's South-South cooperation objectives around training, technology transfer and knowledge exchange (Mawdsley, 2011), continues to operate. A recent iteration is a $\$ 1$ billion e-network connecting universities and hospitals (Cheru \& Obi, 2011; Carmody, 2013). Beyond technical cooperation, Narlikar (2013; Hurrell \& Narlikar, 2006) has shown how Nehruvian expressions of solidarity with developing countries continued to influence India's 21st century diplomatic negotiations. However, there is debate on the extent to which South-South Cooperation principles matter beyond rhetoric and translate into concrete contemporary policy positions. With regard to China, Alden and Large (2011, p 35) have asserted a tendency to "fold together classic assertions of modernisation theory, mercantilist self-interest and actual development experience with the open-ended rhetoric of South-South Cooperation". We now turn to the Exim Bank loan scheme and its workings in Africa to assess this via a specific case study.

\section{The Exim Bank LoCs}

\subsection{Origins}

As with India's development cooperation more widely, the provision of ad hoc demanddriven concessional credit to other developing countries dates to the mid-20th century (Saxena, 2016a). However, the first systematic concessional credit scheme started in 2003, eventually implemented as the Indian Development and Economic Assistance Scheme (IDEAS) under the UPA administration in 2005 (Saxena, 2016b). The scheme's key innovation was 'interest equalisation support', a payment by the Indian government to subsidise the interest rate demanded by the Exim Bank, which was typically between 1\% and 3\%, with a loan maturity of 10-20 years. ${ }^{6}$ The IDEAS scheme was, from the start, framed in terms of South-South Cooperation. Requirements for $75 \%$ of the loan's value to be spent on Indian content ensured win-win benefits, supporting the internationalisation of Indian businesses. Additionally, officials asserted the importance of the scheme's 'ondemand basis', without a sectoral strategy: the Indian "government does not want to dictate" and so follows a "needs based principal". ${ }^{7}$ Moreover, given that "sovereignty was a priority ... we asked the country to do the bidding and selection of a company ... we would rubber stamp [their decision]". ${ }^{8}$ From its inception, the IDEAS scheme was a key pillar of development cooperation and played a particularly significant role in relations with Africa. The high-level political summits focused on concessional finance and support for infrastructure, with the 2008 India-Africa Forum Summit pledging \$5.4 billion (Dubey \& Biswas, 2016), increased to $\$ 10$ billion at the 2015 event (Government of India, 2015). Thus, although a global scheme, African countries have received a significant share of the LoCs. Between 2004 and 2014, African states were involved in 133 out of 187 loans, amounting to $\$ 6.28$ billion of $\$ 10.21$ billion lent by the Exim Bank (Singhal \& Qadri, 2014).

\footnotetext{
${ }^{6}$ The international standard interbank lending rate based on trading in the city of London.

7 Interviews, Senior Official 1 and Junior Official 1, Exim Bank, 2016.

8 Interview, Senior Official 4, DPA, 2020.
} 
4.2 Evolution: non-conditionality to imposed standards

2005-10: the primacy of a political, not project-based decision

As illustrated by Figure 1, the official LoC process was initially conceptualised as starting with an African government. A government would approach the Indian government about a project, and then agree technical terms with the Exim Bank around the interest rate and Indian content. A central feature from the beginning was the way that political approval came before assessment of the project itself, with the decision based on bilateral relations with the recipient country. ${ }^{9}$ African governments could also request additional training schemes in conjunction with the LoC, as happened in the Nyabarongo Dam in Rwanda, one of the largest schemes to be approved in the first five years of IDEAS. As well as financing $80 \%$ of the dam's initial cost, India supported the training of operation engineers.

\section{0-15: light-touch regulation and growing bureaucracy}

This process was first reformed when IDEAS was renewed in $2010,{ }^{10}$ as captured in Figure 2. The Indian government wanted to introduce a requirement for projects to have conceptualisation documents and feasibility studies, so it mandated Detailed Project Reports (DPRs). However, the requirements were still relatively open in terms of the reports' content and standards (Saxena, 2016a). The government also introduced monitoring: it was "not in place at the beginning", but this "hands-off" process "evolved", according to a senior Exim Bank official, ${ }^{11}$ and it featured reviews every six months post-2010 (Saxena, 2016b). Further change came with an alignment of interest rates to the IMF classifications of heavilyindebted, low- and middle-income countries, and standardisation of interest subsidies in line with the World Bank. This shows a specific instance of deliberate adoption of policies from the Bretton Woods establishment. A further change occurred in 2012, with the introduction of the Development Partnership Administration (DPA). Though not established as an independent agency, this was created to support the MEA's rapidly increasing workload (Taylor, 2016); as one official put it, "stronger implementation [was] needed". ${ }^{12}$ Thus, while answering to the MEA, the DPA was India's first formal external development bureaucracy, increasing the country's ability to assess, monitor and process cooperation projects.

\footnotetext{
${ }^{9}$ Interviews, Senior Officials 1, 2, 4, DPA; former Senior Officials 1 and 3, MEA, 2016-20.

10 Interview, Senior Official 4, DPA, 2020.

11 Interview, Senior Official 1, Exim Bank, 2016.

12 Interview, Senior Official 3, DPA, 2020.
} 
Figure 1: The official LoC process pre-2010 reform

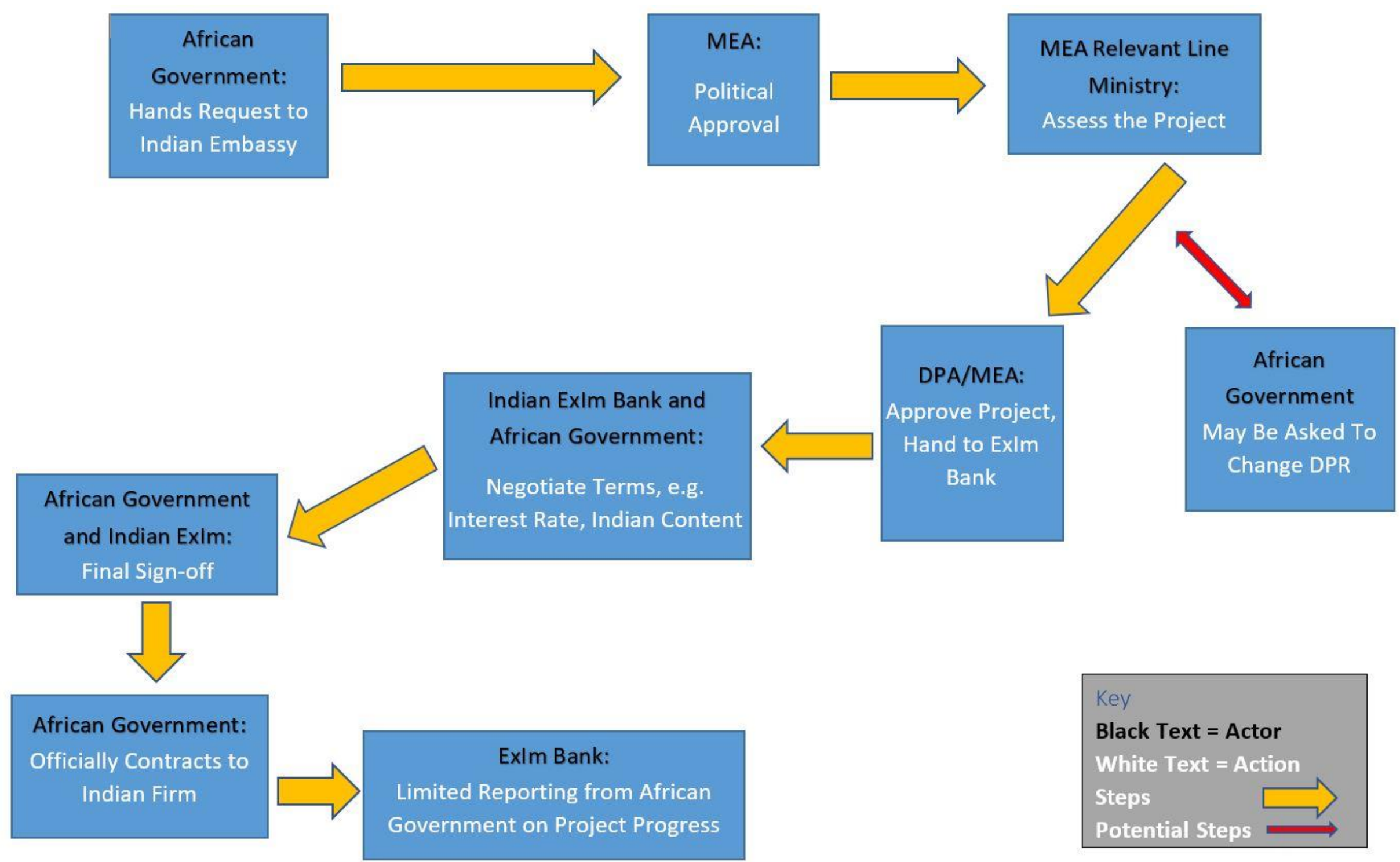


Figure 2: The LoC process occurring in practice post-2010 when involving prior agreement with an Indian company

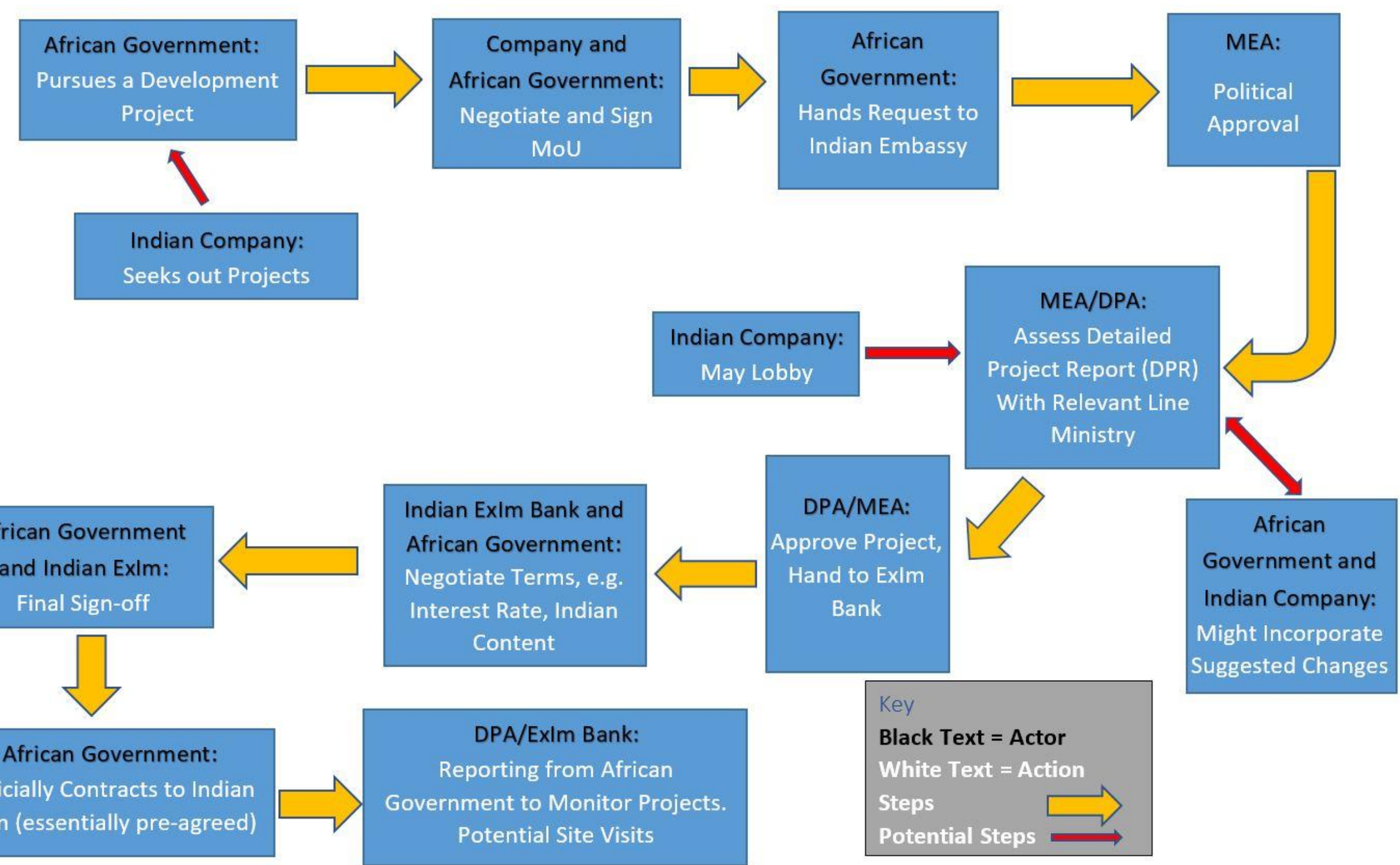


However, this process, and particularly its starting point of a request from an African state, was frequently not followed. As Figure 2 shows, in practice Indian companies sought out projects and secured agreements with governments in Africa. Here, the Indian company essentially worked to advertise the IDEAS scheme. Nevertheless, such pre-agreements, and occasional roles in project preparation and implementation, also subverted the embedded assumption of open, competitive tendering. ${ }^{13}$ This practice underpinned the rise of an entrepreneurial group of 'jack-of-all-trade' companies at the heart of the 2015 scandal outlined in the Introduction. The largest firm here was Angelique International, followed by Overseas Infrastructure Alliance (OIA), Lucky Exports and Jaguar Overseas. While individuals within the companies might have had some experience, the firms themselves were relatively new creations and undertook the full range of infrastructure projects, regardless of how technically demanding these were and despite their inexperience. Based on publicly available data, the author's estimates suggest that Angelique, OIA and Jaguar alone were involved in $57.5 \%$ of the LoCs, when measured by value. The rise of these firms thus became an important driver of a major change to the IDEAS scheme in 2015.

\subsection{The 2015 change}

A dramatic shift in the tendering, monitoring and conceptualisation of LoC projects came in November 2015, as captured by Figure 3. The most overt change concerned the decision to "do the tendering process ourselves ... [rather] like the World Bank", ${ }^{14}$ with the Exim Bank ensuring an open, competitive process involving only pre-approved, 'empanelled', companies. Firms' capacity and Indian experience would be requirements for empanelment, in order to filter out smaller, less experienced companies. ${ }^{15}$ The guidelines also now included provision to include a project management company, not just an implementing contractor. As one senior Exim manager stated, this was in order to support Indian project management companies and ensure higher construction standards. ${ }^{16}$ It was echoed by others in the DPA: having "a project management consultant, [I] always think it is better" for project completion and timeliness. ${ }^{17}$ The World Bank directly informed these new processes: we "worked closely with the World Bank to develop robust systems, appropriate guides ... best practices shared by World Bank". ${ }^{18}$ Consequently, guidelines on the IDEAS LoCs directly refer to World Bank regulations (Exim Bank, 2017), and the Exim Bank is currently working on plans for a blacklist mechanism to exclude those contravening regulations, in line with other multilateral development banks. ${ }^{19}$ However, aware of the lengthiness of the tendering processes undertaken by the World Bank and other 'traditional' multilaterals (often up to 24 months), officials also sought to "expedite" procedures where possible. ${ }^{20}$

\footnotetext{
13 Interview, Former Senior Official 5, MEA, 2020.

14 Interview, Senior Official 1, Exim Bank, 2016.

15 Interview, Senior Official 4, DPA, 2020.

16 Interview, Senior Official 1, Exim Bank, 2016.

17 Interviews, Senior Officials 3 and 4, DPA, 2020.

18 Interview, Senior Official 2, Exim Bank, 2020.

19 Interview, Senior Official 2, Exim Bank, 2020.

20 Interview, Senior Official 4, DPA, 2020.
} 
Figure 3: Depicting the post-2015 IDEAS LoC process

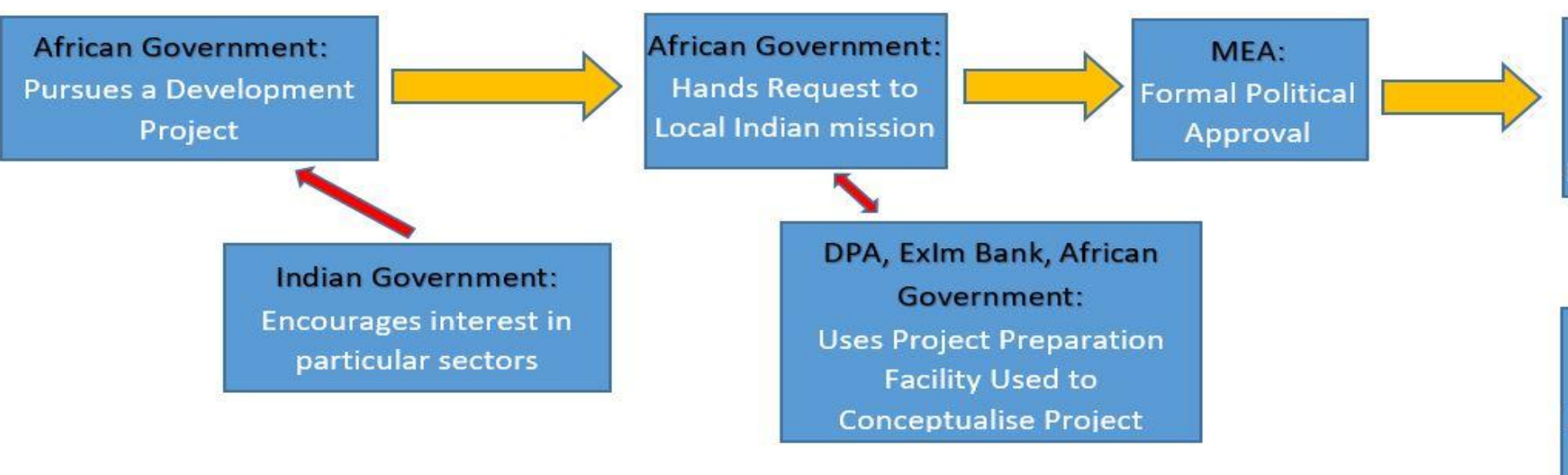

DPA-ExIm Bank:

Sanction $1 \%$ of the LoC's Value for Producing DPR (Technical Feasibility and Financial Studies)

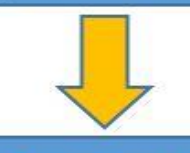

ExIm Bank:

Conducts Open Tendering to Recruit an Indian Consultancy

to Produce DPR

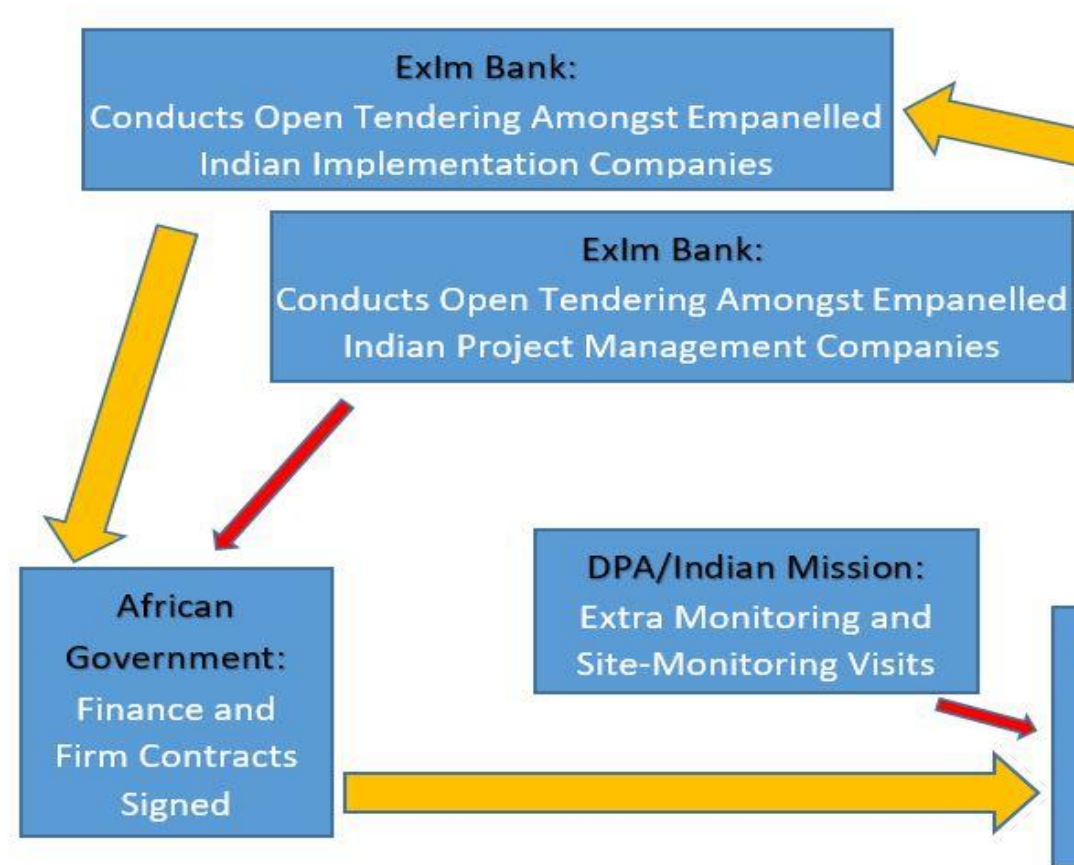
DPA/ExIm Bank/Indian Mission/ African Government:
Quarterly Video Conference Biannual In-Depth Reviews Site-Monitoring Visits

DPA, Relevant Line Ministry, External/Governmental Consultant

Assess Detailed Project Report

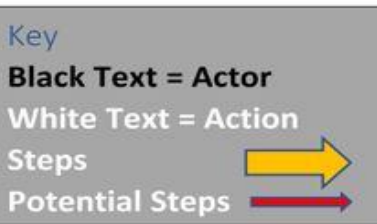

Potential Steps $\longrightarrow$ 
A second reform area concerned reporting and monitoring. The new regime involves quarterly teleconferences, with in-depth reviews every six months. Although the "MEA can be a very ivory tower [organisation], not always into details .... Now they are doing reviews up to every month for delayed projects." ${ }^{21}$ Moreover, diplomatic "missions ... [now have] a more active role [in contrast to] ... in the past [when the LoCs were the] ... least of their priorities". ${ }^{22}$ Now an officer is accountable for monitoring projects and tasked with conducting site visits, especially for those falling behind schedule (Ministry of Finance, 2015; Exim Bank, 2017).$^{23}$ Further, at the end of the project, the recipient is required to produce an evaluation (Exim Bank, 2017) focusing on performance, timeliness, budget and wider economic benefits. ${ }^{24}$ This constitutes the first time the Indian authorities have assessed a project's impacts, albeit without influencing conceptualisation or approval. In addition, in another example of taking direct inspiration from DAC organisations, a 'DfID²5-Exim tie-up' involved the transposing of software used by the UK to monitor, report and record aid projects.

A final set of changes - which has arguably shifted India from its demand-driven startingpoint - focused on the conceptualisation and planning of projects. The changes stemmed from an apparent realisation that many recipients did not have the capacity to develop project conceptualisation to sufficient standards. ${ }^{26}$ There was even "a view in the ministry that African governments don't know what they want". ${ }^{27}$ As an example, one official described a West African country approaching the MEA for a $\$ 50$ million irrigation project without specifying what type of infrastructure (for example, canal or pump irrigation), or crop, they had in mind, meaning that "hand holding has to happen". ${ }^{28}$ The solution to these issues was the creation of a Project Preparation Facility, a pot of money that could pay for a consultant to produce a pre-feasibility report and, if necessary, propose details of a workable project. Relatedly, Indian authorities now project ideas of what areas they want to engage in. Official documents list infrastructure and economic projects as a first priority for IDEAS, followed by bilateral trade, goods and services and, lastly, network service and facilities. While this is a very broad list, prioritising sectoral engagement is a step removed from the previous policy of open-ended, demand-led approaches. Interviewed officials went further. One reported a widespread idea that "[we are] trying to get them [recipients] to demand what we feel they should". ${ }^{29}$ This is linked to ambitions to join projects together in a sectoral focus to increase their economic benefits, ${ }^{30}$ something that would at the very least involve suggesting schemes to recipients. As one DPA official described it:

What we are doing this year is a 'Master Sector Approach' that focuses more on sectors like railways or healthcare and 'suggests projects' that will be more

\footnotetext{
21 Interview, Senior Official 4, DPA, 2020.

22 Interview, Senior Official 1, DPA, 2016.

23 Interviews, Senior Official 2, Exim Bank; Senior Officials 3 and 4, DPA, 2020.

24 Interviews, Senior Officials 3 and 4, DPA, 2020.

25 UK's Department for International Development

26 Interview, Senior Officials, 1, 3, 4, DPA, 2016-2020.

27 Interview, Senior Official 3, DPA, 2020.

28 Interview, Senior Official 4, DPA, 2020.

29 Interview, Senior Official 3, DPA, 2020.

30 Interviews, Senior Officials 1, 3, 4, DPA; Senior Officials 1 and 2, Exim Bank, 2016-20.
} 
joined up. This is in response to finding that 'African governments don't (always) know what they want to do ... we are trying to ... get them to demand what we feel they should. ${ }^{31}$

Such ambitions are far more like those of DAC-member aid agencies and the World Bank. They tend to play a proactive role in identifying needs, defining projects and thinking across sectors to achieve development outcomes.

Alongside project conceptualisation, there is far greater stringency in assessment. The introduction of DPRs in 2010 produced documents of variable quality, described as being "sketchy" or a "ragbag" of reports, sometimes written by "a consultant that hasn't actually visited the country". ${ }^{32}$ The new procedures made arrangements for $1 \%$ of the LoC value to be spent on DPRs, with attention primarily focused on detailed feasibility reports, financial viability and 'good' quality. For this, an Indian consultant would be contracted (Ministry of Finance, 2015; Exim Bank, 2017). Additionally, alongside a line ministry, a government or external consultant now assesses DPRs, ${ }^{33}$ with further changes requested if they are not up to standard. Recipients must now also prove that "right of way issues" are obtained before approval. ${ }^{34}$ This demand reacts to experienced delays ${ }^{35}$ and refer to the acquiring of land, obtaining of tax exemptions for Indian exports and the securing of environmental and other governmental clearances (Exim Bank, 2017). As shown in Figure 3, political approval still precedes assessment processes: officials noted that "we have a problem with rejection" ${ }^{36} \mathrm{At}$ least in 2016, the Ministry of Foreign Affairs "doesn't refuse [LoCs] frequently", even when project reports are inadequate, as "our endeavour is to accept and if problems, work with [the partner government to sort them out]". ${ }^{37}$ However, the presence of such scrutiny and requirements increases the stringency of the planning process and, necessarily, the bureaucratic burden on the recipient.

\section{How far is this a shift from earlier South-South cooperation? The unevenness of convergence}

The evidence presented here therefore points to the 2015 LoC changes creating a pattern of 'uneven convergence'. In areas of technical performance, the Indian state adopted a number of standard World Bank policies and some of the modalities typical in DAC aid, but it did not shift from principles centring on respect for sovereignty or a state-to-state focus. This policy change is significant, moving from open-ended, demand-led, non-interventionist SouthSouth Cooperation to a situation in which the Indian state now controls and mandates competitive tendering, while determining the details of implementation, whether in the use of a project management consultant, the volume of reporting or conduct of an ex post evaluation. More fundamentally, the 2015 changes demonstrate an ambition within the DPA and the Exim Bank to have a larger role in choosing projects in areas where India has

\footnotetext{
31 Interview, Senior Official 1, DPA, 2016.

32 Interviews, Senior Official 1, DPA; Senior Official 1, Exim Bank, 2016.

33 Interview, Senior Official 2, Exim Bank, 2020.

34 lbid.

35 One interviewee told of visiting a fish processing plant in Ghana, which was constructed but closed, as it had no environmental permit.

36 Interview, Senior Official 2, DPA, 2016.

37 Ibid.
} 
specialisms and in linking them to form sectoral approaches. Collectively these changes aim to increase the technical proficiency of Indian development cooperation so that functioning, effective projects can be delivered reliably, with the Indian state and companies then able to reap the reputational and strategic advantages.

This echoes a wider discussion in Indian policy circles. Aneja and Ngangom (2017), for example, argue that DPA would benefit from developing an intellectual agenda like the World Bank's and increasing its independence and capacity to that of DfID or GIZ.

Meanwhile RIS (Research and Information System for Developing Countries) advocates a 'development compact' (Chaturvedi, 2016; Chaturvedi \& Mohanty, 2016) that conceptualises joining up development cooperation activities into a sectoral intervention, specifically involving technology transfer, grants, capacity building, trade and concessional finance (Singhal \& Qadri, 2014; Saxena, 2016b, 2016a). The oft-cited exemplar mentioned in various publications (FIDC \& RIS, 2015) and by DPA and Exim Bank officials is Ethiopia. ${ }^{38}$ Here, India supplied a \$607 million loan for three sugar-processing factories attached to biogas electricity generators. These changes are intended to increase the potential effectiveness of India's cooperation projects, boosting their impact in recipient countries by making cooperation greater than the sum of its parts.

Notably, convergence has not occurred in practices concerning broader rhetorical norms and attention to individual project outcomes for citizens and the environment. South-South Cooperation rhetoric is still frequently deployed. Incumbent Prime Minister Modi and his government reduced the use of this language at first, given that their Bharatiya Janata Party (BJP dislikes associations with Nehru (Harris \& Vittorini, 2018), but this has changed recently. ${ }^{39}$ Modi pledged $\$ 150$ million to the UN's South-South Cooperation fund in 2018, for instance (Ramachandran, 2019). Moreover, interviewed officials continue to insist that India's development cooperation and IDEAS schemes were "non-conditional ... demand driven", ${ }^{40}$ and "not prescriptive like the Western approach", despite the LoC changes. ${ }^{41}$ Furthermore, as stated above, assessment of whether to approve a loan is fundamentally based on state-to-state relationships, not project appraisal: increased attention to project viability has not trumped the primacy of political imperatives in the approval process. This underlines a continuing gap in attention to project outcomes. The 2015 regulatory changes did, for the first time, focus on implementation, but attention here was on feasibility, precise details around finance, construction logistics and monitoring, to ensure projects are on time and within budget. Unlike Brazil's BNDES or China's Exim Bank, India does not require prior impact assessments. Convergence has therefore taken place in engineering and management standards, but not in socio-environmental assessment. Arguably, this demonstrates a persistent South-South Cooperation premise that recipient states are responsible for their citizens and territory; the recipient government, rather than the Indian

\footnotetext{
38 Interviews, Senior Officials 1, 3, 4, DPA 2016-20; Senior Official 1, Exim Bank, 2016: "[We] would love to be [more] united as an aspiration".

39 'PM Modi urges greater South-South cooperation to address climate change, biodiversity, degradation'. India.com News Desk, 11/6/2019; interviews with researchers at RIS and Observer Research Foundation; Indian Council on World Affairs (2020).

40 Interviews, Senior Official 3, DPA, 2020. "don't like to impose, entirely demand driven" (Interview, Senior Official 2, Exim Bank, 2020.

41 Interview, Senior Official 4, DPA, 2020.
} 
state, takes the role of caring for a project's positive or negative socioeconomic impact. India's role is only in ensuring technical functionality. This pattern is not unique. Mohan and Tan-Mullins (2018) have described the elite-centric nature of China's developmentcooperation decision making, which leads to what Urban et al (2013) have described as the abdication of responsibility for thinking about developmental and environmental impacts.

\section{Motivations for the 2015 changes to IDEAS: bilateral relations merged with corporate and political interests}

This uneven convergence is driven by the political motivations behind the 2015 LoC changes. Strategic interests are the key drivers behind India's extension of subsidised credit, central to which is a desire to build closer diplomatic ties. India seeks the votes of African states to achieve its international agenda at multilateral negotiations, whether on trade, climate or UN Security Council reform. ${ }^{42}$ Further, India wants to build an Indian Ocean sphere of influence, partially to counter its rival China (Beri \& Institute for Defence Studies and Analyses, 2015). Moreover, "India has pushed its Africa connection not simply to score diplomatic points but also to achieve a foothold in an energy and mineral rich region" (Saxena, 2016b, p 66). As Biswas (2015) notes, securing oil was a key concern for India in the mid-2000s, leading to deliberate efforts to build ties with Africa's established and emerging petro-states. The LoC scheme was one way of improving diplomatic relations, thereby supporting Indian access to oil and other key minerals. ${ }^{43}$ Given that the IDEAS scheme was "a diplomatic instrument", ${ }^{44}$ India also financed prestige projects, including Ghana's Presidential Office, Gambia's Parliament and Niger's International Convention Centre.

This same diplomatic rationale partly prompted the 2015 changes: for LoCs to build goodwill, the Indian government judged that projects needed to function technically and be delivered on time and within budget. ${ }^{45}$ Indian projects delivering development and fulfilling the ambitions of recipients would be more diplomatically valuable. As one official explained, "we were facing a problem of lengths of projects". This was difficult for the political element to the LoCs. "[We wanted] closer ties with certain countries ... [as] we were wanting that country to develop, otherwise they would think what are these guys doing?"46 Thus, during its first ten years, the record of the LoCs in Africa caused growing concern. As stated above, African governments were reportedly complaining about such projects. Some complaints recorded by the author relate to a Ghanaian fish-processing plant, a Rwandan irrigation project and two hydropower dams in the Central African Republic. Whitfield (2018) also records a $\$ 35$ million cement plant in Ghana that was not sufficiently capitalised and had insufficient land to supply materials for cement manufacture, causing the project to stall within a year. Thus, Indian officials feared for the "image of India", ${ }^{47}$ because "major projects were not formulated or executed after signing"; 48 concessional finance could have "done damage instead of

\footnotetext{
42 Interviews, former Senior Officials 1, 3, 4, MEA, 2016-20.

43 Such as copper, diamonds and phosphates.

44 Interview, Senior Official 4, DPA, 2020.

45 Interview, former Senior Official 4, MEA, 2020.

46 Interview, Senior Official 1, DPA, 2016.

47 Interview, think-tank researcher, 2016.

48 Interview, Senior Official 4, DPA, 2020.
} 
availing goodwill and a visible project" (Saxena, 2016a, p 45). Exim Bank and DPA officials felt that project planning was to blame, leading to spending on feasibility reports alongside greater use of consultants and project management firms. In particular, the four inexperienced generalist companies were blamed, ${ }^{49}$ with many alleging corruption: "unsavoury practices were gaming the system". ${ }^{0}$ In the case of Angelique, this was seemingly confirmed by the World Bank blacklisting the company for corruption. ${ }^{51}$ Thus, the new empanelment and tendering process, which emphasised experience and operational record in India, was designed to exclude such companies; so that the "project is done well [we should] broaden the base [of contracting companies]", we need "good companies", unlike in the past. ${ }^{52}$

However, officials in the DPA and Exim Bank were not the only influence. India's private sector has long played a key role in shaping relations with Africa, either using its own agency, or through its ability to effectively lobby the government to start schemes, including IDEAS credit (Taylor, 2016). Private sector federations, and particularly the Federation of Indian Chambers of Commerce \& Industry (FICCI) and Confederation of Indian Industry (CII where Africa relations are concerned have bolstered this influence. An additional driver, acknowledged by government officials, for the exclusion of the smaller generalist firms from the IDEAS LoCs came from the larger, established Indian engineering firms like Shapoorji \& Pallonji, Afcons (now the former's subsidiary), Larsen \& Toubro and the Tata Group. ${ }^{53}$ These companies argued that, with such corruption, they "didn't stand a chance";54 "one of the good outcomes is they [the smaller insurgent firms] are now out ... [The changes] provided for the serious players" ${ }^{55}$ Additionally, party-political interests may have played a role. A number of interviewees referred to OIA's and Angelique's financial connections with the Congress party. ${ }^{56}$ With Congress losing the 2014 election, the BJP government could have taken the opportunity to remove these potentially politically connected firms. Indeed, a former OIA employee said that the firm was told to "take a step back or change your way of doing business" - meaning that it should change its politically connected investors and financial backers. ${ }^{57}$ Such allegations are unsurprising, given the widespread use of public contracts to create rents for India's political parties. While Angelique is barred from IDEAS during its period of World Bank blacklisting, interviewees from OIA and Jaguar Overseas also reported that they had been effectively frozen out and were not receiving any new IDEAS contracts. ${ }^{58}$ Figure 4 demonstrates this marked decrease, and then cessation of LoCs involving three of the 'entrepreneurial' firms.

\footnotetext{
49 The abovementioned Angelique, OIA, Lucky Exports and Jaguar Overseas.

50 Interview, Senior Official 1, Exim Bank, 2016. This was echoed in interviews with the DPA, former ambassadors and think-tanks between 2016 and 2020.

51 'Several Indian companies debarred by World Bank in 2018'. Economic Times, 2 February 2020.

52 Interviews, Senior Officials 1 and 3, DPA, 2020.

53 Interviews, former Senior Officials 3 and 4, MEA, 2020.

54 Interview, senior official, Shapoorji \& Pallonji, 2020,

55 Interview, senior official, Afcons, 2020.

56 Interviewed in Delhi and Mumbai, 2020.

57 Interview, former senior official, OIA, 2020.

58 Interviews, senior officials, OIA and Jaguar Overseas, 2020. For example, Jaguar was frozen out of the Bulawayo Power project. https://www.herald.co.zw/re-powering-project-faces-hurdle. Accessed: 16 July 2020.
} 
Figure 4: Demonstrating the rise and fall of three of the 'new' firms

Aproximate Number of ExIm Bank Projects For Angelique International, Overseas Infrastructure Alliance and Jaguar Overseas

800

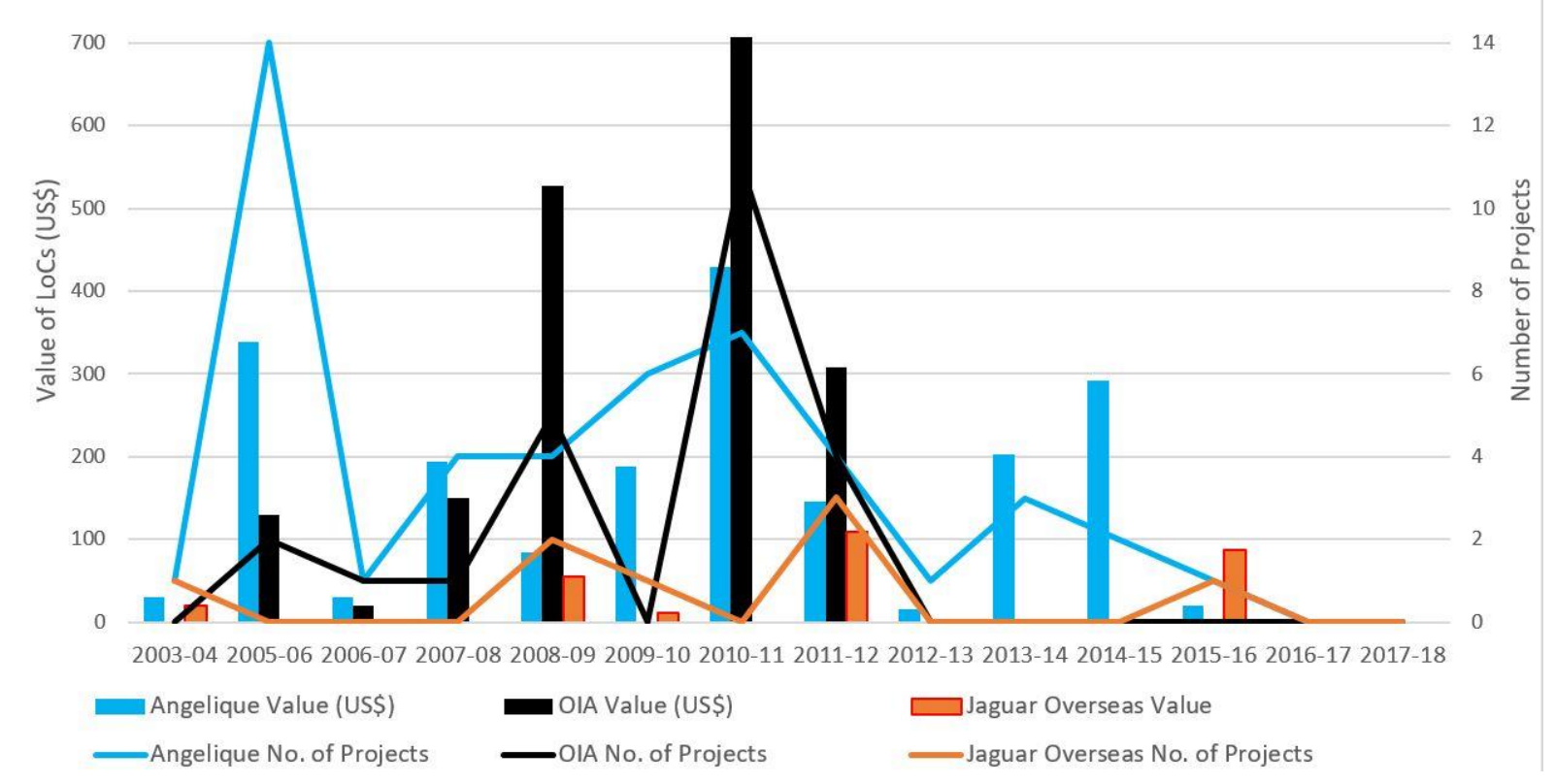

7 The unintended consequences of convergence and the overlooked factors underpinning the IDEAS LoCs

Rather than any easy transition and continuation, the reforms triggered a reduction in the volume of IDEAS projects, especially in infrastructure. Figure 5 illustrates the fall in infrastructure LoCs to Africa from 62 projects, at a value of $\$ 4.01$ billion, between 2010 and 2015 to 29 , valued at $\$ 2.81$ billion, between 2015 and 2019. ${ }^{59}$

${ }^{59}$ Author's calculation based on Exim Bank statistics. 
Figure 5: The reduction in infrastructure financing from 2015

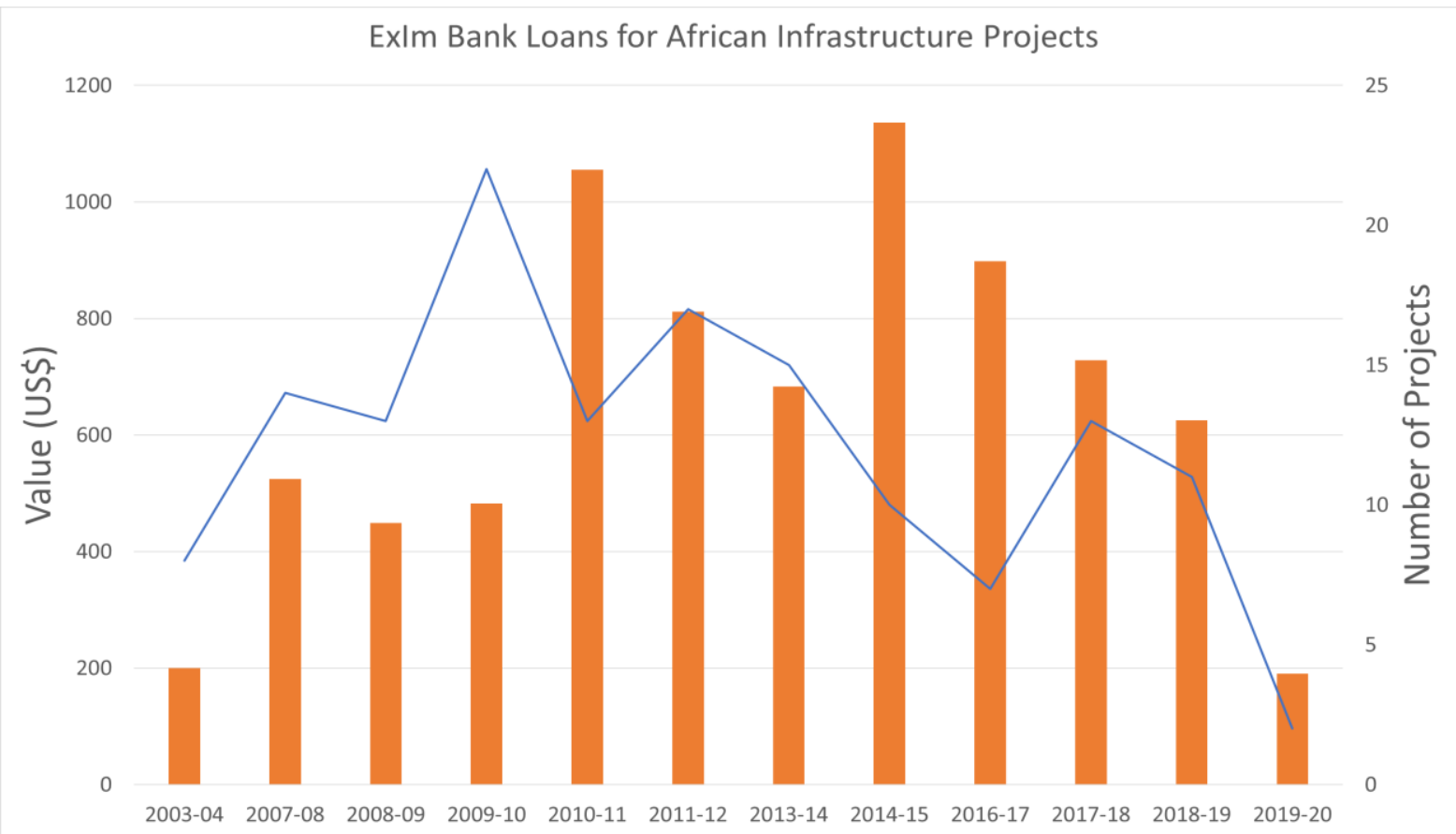

\section{-Value (US\$) -Number of Projects}

Source: Statistics collected by the author from Exim Bank.

There are a number of factors behind this. One relates to the increased burden placed on the MEA, diplomatic missions, DPA and Exim Bank by the 2015 changes. India's bureaucratic weaknesses are well known, with Bajpai and Chong (2019) demonstrating organisational and staffing shortfalls in the MEA specifically. This matters, because, whereas previously the 'entrepreneurial' infrastructure firms played the role of advertising agents, spreading the IDEAS uptake, only the government can now take this activist role, since competitive tendering does not reward the making of pre-contract deals. A recruitment surge in MEA has occurred since $2012,{ }^{60}$ but staff shortages, particularly in embassies in Africa, have curtailed the country's capability. ${ }^{61}$ Thus, some interviewees felt that taking "away the spearhead companies" was an issue, with most large infrastructure firms having "no contacts on the ground" and being overly risk-averse. ${ }^{62}$. The most successful firms now appear to be Shapoorji \& Pallonji and its subsidiary Afcons, which are in this position partly because of their on-the-ground presence: Shapoorji \& Pallonji has regional offices in West, East and Southern Africa, for example.

Another factor behind the reduction in IDEAS LoCs has been disquiet among African governments. Previously the absence of paperwork was a perceived major advantage to

\footnotetext{
60 Interviews, former Senior Officials, 3 and 4 MEA, 2020.

${ }^{61}$ Bajpai and Chong (2019) have reported persistent issues of unfilled posts and there were only 20 ranking diplomats for Africa in 2014 (Taylor, 2016).

62 Interviews, former Senior Official 4, MEA; researchers and former Senior Officials 3 and 4, MEA; former and current senior officials, OIA, 2020.
} 
India's concessional lending (Dye, 2016). Thus, interviewees in embassies, ${ }^{63}$ the Indian government and various think-tanks blamed increased planning stringency for decreased appetite:64 one reported African partners stating: "you ask so many questions and the Chinese don't". ${ }^{65}$ Moreover, while Indian researchers and officials understood African frustration that the new regulations were "impinging on their sovereign role", ${ }^{66}$ none discussed the potential role that public sector contracts could have for governments in Africa. Clapham (1996) and many others have shown the way some states use international finance for political ends, awarding contracts to regime supporters, or to build up electoral coffers. This could help explain frustrations around the new tendering system and why some African governments have turned from IDEAS LoCs to the Exim Bank's buyer's-credit loans. They are not part of the development cooperation subsidised IDEAS scheme and operate roughly according to the pre-2015 process, awarding money directly to an Indian company based on its contract with a recipient company or government. Buyer's credit therefore allows Indian companies to forge agreements with governments in Africa outside political MEA approvals. Shapoorji \& Pallonji-Afcons have increasingly used this mechanism, including for an under-construction $\$ 425$ million railway in Ghana (Ministry of Finance, 2017). Overall, the apparent lack of anticipation of these issues, at least as shown in Indian government documents and among interviewed officials, arguably speaks to the frequent absence of African voices and perspectives in India's development cooperation with the continent.

\section{Conclusion}

In conclusion, uneven Indian convergence in its subsidised infrastructure-finance scheme stems from a set of political rationales. Diplomatic and party-political motivations converged to drive a set of policies aiming to increase technical proficiency, timeliness and development outcomes, but also a change in the companies undertaking these projects. This led to the adoption of a set of specific policies around project selection and design, tendering and monitoring that were directly taken from the World Bank and other DAC donors. India's 2015 LoC changes consequently reveal a degree of convergence in international development. This demonstrates a departure from the non-interventionist, minimal-conditions policies and the strict non-hierarchical norm of India's original SouthSouth Cooperation, where the recipient was exclusively handed the decision-making role over what projects were to be undertaken and how; that role is now to some extent shared. However, while converging in these aspects of technical planning and implementation, prior assessments of a project's developmental or environmental outcomes have been conspicuously absent. Rhetorical insistence on respect for sovereignty and on principles of equality has thus maintained a state-to-state modality that focuses on the wants of governments, not of their citizens. The Indian government's emphasis is on improving, not rejecting, proposals.

63 Interview, senior official, Ghanaian Embassy, 2019.

64 Interviews, former Senior Officials 3 and 4, MEA, 2020; staff at think-tanks, Delhi and Mumbai, 2016-2020.

65 Interview, Senior Official 1, DPA, 2016.

66 Interview, Senior Official 4, DPA, 2020. 
The result is therefore an uneven convergence. India is keen to engage with the 'traditional' aid establishment of DAC donors and the Bretton Woods institutions, but on its own terms and to fulfil its own agendas. Indian officials interviewed asserted the uniqueness of their approach and the continuing relevance of South-South cooperation, at least where it pertains to sovereignty and government-to-government relationships. Furthermore, officials rejected comparisons with 'Western' aid. This suggests that the multidirectional convergence era will remain significantly heterogeneous. India's growing economic wealth, political prowess and increasing experience of conducting development cooperation indicate that this is unlikely to change. Rather, a policy evolution appears to be underway that is building a self-confident and unique Indian government approach to development cooperation. Overall, this suggests that, within the multidirectional convergence era, significant and persistent heterogeneity is likely.

However, India's convergence in concessional finance has had unintended consequences. Rather than continuing the rate of increase in IDEAS loans and thereby delivering a high volume of functioning projects, LoCs to African countries have decreased. This demonstrates the weak capacity of India's development bureaucracy and Foreign Service, something which recent announcements on increases in staff and African embassies, for example, may start to address. Equally, it shows the potential challenges of increasing intervention and 'paperwork' requirements for the emerging powers' development cooperation programmes. Straying too far from the perceived advantages of their approach may lessen interest in what is a competitive space for development finance. A more unwelcome conclusion of these unintended consequences, however, is their exposure of the limited knowledge among Indian officials of the political realities and interests of governments in Africa. Addressing this is likely to be crucial for ensuring the LoCs scheme's success and its ability to achieve the desired strategic and diplomatic outcomes.

\section{References}

Alden, C. and Large, D. (2011). 'China's exceptionalism and the challenges of delivering difference in Africa'. Journal of Contemporary China 20, 21-38.

Aneja, U. and Ngangom, T. (2017). Learning from the Old, Preparing for the New: Designing an Institutional Architecture for India's Development Partnerships. Observer Research Foundation (ORF) Working Paper. New Delhi: ORF

Bajpai, K. and Chong, B. (2019). 'India's foreign policy capacity'. Policy Design and Practice 2, 137-162.

Beri, R. and Institute for Defence Studies and Analyses (eds) (2015). India and Africa: Common Security Challenges for the Next Decade. New Delhi: Pentagon Press in association with Institute for Defence Studies and Analyses.

Bhatnagar, A., Passi, R. and Observer Research Foundation (eds) (2016). Neighbourhood First: Navigating Ties under Modi. New Delhi: ORF.

Biswas, A. (2015). 'India's energy security issues and African oil'. In Beri, R. and Institute for Defence Studies and Analyses (eds), India and Africa: Common Security Challenges for the Next Decade. New Delhi: Pentagon Press in association with Institute for Defence studies and Analyses.

Bräutigam, D. (2011). The Dragon's Gift: The Real Story of China in Africa. Oxford: Oxford University Press.

CAFOD and Wykes, S. (2020). CDC's Energy Investments: Building Just, Green Development?. London: Catholic Agency for International Development.

Carmody, P.R. (2011). The New Scramble for Africa. Cambridge: Polity Press. 
Carmody, P.R. (2013). The Rise of the BRICS in Africa: The Geopolitics of South-South Relations. London: Zed Books.

Chaturvedi, S. (2016). The Development Compact: A Theoretical Construct for South-South Cooperation. Research and Information System for Developing Countries (RIS) Working Paper 203. Delhi: RIS.

Chaturvedi, S. and Mohanty, S.K. (2016). Indian Development Cooperation: A Theoretical and Institutional Framework. Policy Brief 7. London: Forum for Indian Development Cooperation (FIDC).

Cheru, F. and Obi, C.I. (2011). 'India-Africa relations in the 21st century: genuine partnership or a marriage of convenience?'. In Mawdsley, E. and McCann, G. (eds), India in Africa: Changing Geographies of Power. Cape Town: Pambazuka Press.

Clapham, C.S. (1996). Africa and the International System: The Politics of State Survival. Cambridge: Cambridge University Press.

Dubey, A.K. and Biswas, A. (eds) (2016). 'Appendix A.2: Plan of Action of the Framework for Cooperation of the India-Africa Forum Summit'. In Dubey and Biswas (eds), India and Africa's Partnership: A Vision for a New Future. New Delhi: Springer.

Dye, B.J. (2016). 'The return of "high modernism"? Exploring the changing development paradigm through a Rwandan case study of dam construction'. Journal of Eastern African Studies 10, 303-324.

Dye, B.J. (2020). 'Continuity or change in the infrastructure turn? Reform of the technicians' realm in a World Bank dam'. European Journal of Development Research 32, 627651.

Dye, B.J. and Alencastro, M. (2020). 'Debunking Brazilian exceptionalism in its Africa relations: evidence from Angola and Tanzania'. Global Society, 34 (4) 1-22.

Dye, B.J. and Soares de Oliveira, R. (forthcoming). 'India-Africa relations under the UPA government'. In Laskar, R.K. (ed.), Forging New Partnerships, Breaching New Frontiers: India's Diplomacy during the UPA Rule (2004-2014). Oxford: Oxford University Press.

Enns, C. and Bersaglio, B. (2020). 'On the coloniality of "new" mega-infrastructure projects in East Africa'. Antipode 52, 101-123.

Exim Bank (2017). Handbook on Government of India supported Lines of Credit operated through Export-Import (Exim) Bank of India. Mumbai: Exim Bank.

Fejerskov, A.M., Lundsgaarde, E. and Cold-Ravnkilde, S. (2017). 'Recasting the "new actors in development" research agenda'. European Journal of Development Research 29, 1070-1085.

FIDC and RIS (2015). India-Africa Partnership towards Sustainable Development. New Delhi: Forum for Indian Development Cooperation (FIDC/) and Research and Information Systems for Developing Countries (RIS.

Gray, Kevin, and Craig N. Murphy. 2013. "Introduction: Rising Powers and the Future of Global Governance." Third World Quarterly 34, no. 2: 183-93.

Government of India (2015). India-Africa Forum Summit III: New Hopes, New Horizons. New Delhi: India.

Gulrajani, N. and Faure, R. (2019). 'Donors in transition and the future of development cooperation: what do the data from Brazil, India, China, and South Africa reveal?'. Public Administration and Development 39, 231-244.

Harris, D. and Vittorini, S. (2018). 'Taking "development cooperation" and South-South discourse seriously: Indian claims and Ghanaian responses'. Commonwealth \& Comparative Politics 56, 360-378.

Hensengerth, O. (2013). 'Chinese hydropower companies and environmental norms in countries of the global South: the involvement of Sinohydro in Ghana's Bui Dam'. Environment, Development and Sustainability 15, 285-300.

Hochstetler, K. (2014). 'The Brazilian National Development Bank goes international: innovations and limitations of BNDES' internationalization'. Global Policy 5 , 360365. 
Horner, R. (2020). 'Towards a new paradigm of global development? Beyond the limits of international development'. Progress in Human Geography 44, 415-436.

Hurrell, Andrew. 2014. "Rising Powers in the Emerging Global Order." In John Baylis and Steve Smith, eds. The Globalization of World Politics: An Introduction to International Relations, Sixth edition Oxford; New York, NY: Oxford University Press.

Hurrell, A. and Narlikar, A. (2006). 'A new politics of confrontation? Brazil and India in multilateral trade negotiations'. Global Society 20, 415-433.

Ikenberry, GJ. 2010. "The Three Faces of Liberal Institutionalism." In Alan S. Alexandroff, Andrew Fenton Cooper, Centre for International Governance Innovation, and Woodrow Wilson School of Public and International Affairs, eds. Rising States, Rising Institutions: Challenges for Global Governance Waterloo, Ont. : Washington, D.C: Centre for International Governance Innovation; Brookings Institution Press.

India.com News Desk, (11/6/2019). PM Modi Urges Greater South-south Cooperation to Address Climate Change, Biodiversity, Degradation. India.com.

https://www.india.com/news/india/pm-modi-calls-for-greater-south-south-cooperationto-address-climate-change-biodiversity-land-degradation-

3769419/\#: :text=A\%20centre\%20of\%20excellence\%20would,prevent\%20land\%20d egradation\%2C\%20noted\%20Modi.\&text=Besides\%2C\%20he\%20said\%20that \%20I ndia,on\%20zero\%2Dbudget\%20natural\%20farming.

Ayer, P.V. (20/10/2015). 'Exim Bank's red flag: why most Africa deals go to so few firms?'. Indian Express.

Kahler, Miles. 2013. "Rising Powers and Global Governance: Negotiating Change in a Resilient Status Quo." International Affairs 89, no. 3: 711-29.

Khanna, Parag. 2009. The Second World: How Emerging Powers Are Redefining Global Competition in the Twenty-First Century. New York: Random House Trade Paperbacks.

Kohli, A. (2009). The Dragon on Safari: China's Policy in Africa. New Delhi: Institute of Peace and Conflict Studies.

Kragelund, P. (2015). 'Towards convergence and cooperation in the global development finance regime: closing Africa's policy space?'. Cambridge Review of International Affairs 28, 246-262.

Kumar, S. and Sharma, A. (2015). India's Neighbourhood Aid Policy: Opportunities and Challenges. CUTS International Discussion Paper. Jaipur: CUTS International.

Marcondes, D. and Mawdsley, E. (2017). 'South-South in retreat? The transitions from Lula to Rousseff to Temer and Brazilian development cooperation'. International Affairs 93, 681-699.

Mawdsley, E. (2011). 'The rhetorics and rituals of South-South development cooperation: notes on India in Africa'. In Mawdsley, E. and McCann, G. (eds), India in Africa: Changing Geographies of Power. Cape Town: Pambazuka Press.

Mawdsley, E. (2012). From Recipients to Donors: Emerging Powers and the Changing Development Landscape. London: Zed Books.

Mawdsley, E. (2015). 'DFID, the private sector and the re-centring of an economic growth agenda in international development'. Global Society 29, 339-358.

Mawdsley, E. (2018). 'The "Southernisation" of development?' Asia Pacific Viewpoint 59, 173-185.

Mawdsley, E. (2019). 'South-South cooperation 3.0? Managing the consequences of success in the decade ahead'. Oxford Development Studies 47, 259-274.

Michel, S., Beuret, M., Woods, P. and Valley, R. (2010). China Safari: On the Trail of Beijing's Expansion in Africa. New York: Nation Books.

Ministry of Finance (2017). Ghana signs 'First Amendatory Buyer's Cedit Agreement' and 'Credit Confirmation Statement'. Accra: Ministry of Finance.

Ministry of Finance, Department of Economic Affairs, Bilateral Cooperation Division (2015). Guidelines on Lines of Credit extended by the Government of India to Various Countries under the Indian Development and Economic Assistance Scheme 
(IDEAS). No. 21/3/2015-IDEAS. New Delhi: Ministry of Finance, Government of India.

Modi, R. (2010). 'The role of India's private sector in health and agricultral sectors in Africa'. In Cheru, F. and Obi, C.I. (eds), The Rise of China and Africa in India: Challenges, Opportunities and Critical Interventions. London: Zed Books.

Modi, R. (2013a). 'India's strategy for African agriculture: assessing the technology, knowledge and finance platforms'. In Cheru, F. and Modi, R. (eds), Agricultural Development and Food Security in Africa: The Impact of Chinese, Indian and Brazilian Investments. London: Zed Books.

Modi, R. (2013b). South-South Cooperation: Africa on the Centre Stage. New York: Palgrave Macmillan.

Mohan, G. and Lampert, B. (2013). 'Negotiating China: reinserting African agency into China-Africa relations'. African Affairs 112, 92-110.

Mohan, G. and Tan-Mullins, M. (2018). 'The geopolitics of South-South infrastructure development: Chinese-financed energy projects in the global South'. Urban Studies, 004209801879435.

Naim, M. (10/2009). 'Rogue aid: what's wrong with the foreign aid programs of China, Venezuela, and Saudi Arabia? They are enormously generous. And they are toxic'. Foreign Policy.

Narlikar, Amrita. 2007. "All That Glitters Is Not Gold: India's Rise to Power." Third World Quarterly 28, no. 5: 983-96.

Narlikar, A. (2013). 'India rising: responsible to whom?'. International Affairs 89, 595-614.

Okeke, V.O.S. (2014). 'Chinese incursion and impact in Africa'. Academic Journal of Interdisciplinary Studies 3, 283-293.

Pamment, J. (2018). 'Towards a new conditionality? The convergence of international development, nation brands and soft power in the British National Security Strategy'. Journal of International Relations and Development 21, 396-414.

Panda, J.P. (2013). BRICS and the China-India Construct: A New World Order in Making?. New Delhi: Institute for Defence Studies and Analyses.

Ramachandran, J. (2019). 'India draws the focus for South-South cooperation'. InDepthNews, 29 April.

Saxena, P. (2016a). 'Lines of credit: policy matrix revisited'. International Studies 53, 44-58.

Saxena, P. (2016b). 'India's credit lines: instrument of economic diplomacy'. In Chaturvedi, D. and Mulakala, A. (eds), India's Approach to Development Cooperation. London: Routledge/Taylor \& Francis.

Serrano Oswald, O.R. (2019). 'The new architects: Brazil, China, and innovation in multilateral development lending'. Public Administration and Development 39, 203214.

Singhal, R. and Qadri, A. (2014). Development and Diplomacy through Lines of Credit: Achievements and Lessons Learnt. Occasional Paper 53. New Delhi: ORF.

Taylor, I. (2016). 'India's economic diplomacy in Africa'. In Dubey, A.K. and Biswas, A. (eds), India and Africa's Partnership (pp. 99-113). New Delhi: Springer India.

Urban, F., Mohan, G. and Cook, S. (2013). 'China as a new shaper of international development: the environmental implications'. Environment, Development and Sustainability 15, 257-263.

Whitfield, L. (2018). Economies after Colonialism: Ghana and the Struggle for Power. Cambridge: Cambridge University Press.

Xiaoyu, P. (2012). 'Socialisation as a two-way process: emerging powers and the diffusion of international norms'. Chinese Journal of International Politics 5, 341-367. 